\title{
Realizing the volatility impacts of sovereign credit ratings information on equity and currency markets: Evidence from the Asian Financial Crisis
}

This version: 23 January 2012

\begin{abstract}
We examine the effects of different types of sovereign rating announcements on realized stock and currency market volatilities and cross-asset correlations around periods of financial crises. Using intraday market data and sovereign ratings data for nine sample countries in the Asia-Pacific region over 1997-2001, we find that currency and stock markets react somewhat heterogeneously to various rating announcements and that stock markets are more responsive to rating news than currency markets. We find new evidence that ratings events have significant and asymmetric impacts on intraday market data and that national market attributes influence rating impacts during financial crises.
\end{abstract}

JEL classfication: G15, F30, F31

Keywords: sovereign ratings, realized volatility, realized correlations, foreign exchange, stocks 


\section{Introduction}

Credit rating agencies are entrusted as specialist information providers in international financial markets and should in theory facilitate the efficient operation of financial markets. Yet, the informational value of ratings and the role of rating agencies in the international financial system remains widely debated.

This paper aims to examine the effect of sovereign credit rating and outlook change announcements on the realized second moments of stock returns and foreign exchange rates for nine sample countries in the Asia-Pacific region as previous studies like Kim (2003) and Evans and Speight (2010) have documented significant impacts of public information releases on the second moments of stock and currency returns, respectively. Sovereign credit ratings provide publicly available assessments on a national government's ability and willingness to service debts in a timely manner. As can be seen in Figure 1, credit rating agencies are generally more active in re-rating countries during international financial crises, which are correspondingly highly volatile periods. The procyclical nature of credit ratings generates concern that credit rating agencies may work to amplify financial crises (Ferri et al., 1999). Thus, it is important to assess the wider impacts of rating agencies' credit assessments on the volatilities of financial markets as this evidence remains lacking. Hence, we focus on the volatility impacts of sovereign rating events over the period from 1997 to 2001 to cover previous episodes of financial crises in East Asia and other parts of the world. We employ a flexible panel data methodology for capturing a country's own rating impacts and its spill-over effects to other countries by using intraday currency and stock market data to compute realized volatilities and realized cross-market correlations. 
We find that currency and stock markets react somewhat heterogeneously to ratings announcements with stock markets responding more significantly to rating news than currency markets. Changes on sovereign credit outlooks have more significant impact on stock market realized volatilities than actual rating changes but not so in currency markets. We also find clear evidence that rating events have significant and asymmetric impacts on higher moments of both asset market returns under normal market conditions but during financial crises financial markets are particularly sensitive to rating downgrades and investment grade ratings. Realized cross-market stock-FX correlations increase with downgrades and decrease with upgrades but this asymmetry is not affected by financial crises. The Asian financial crisis (AFC) increased the sensitivity of realized volatilities to different types of ratings information and there were significant interactive effects with national market attributes. Finally, there were marginal rating spillover effects from Indonesia, Philippines and Thailand on other markets’ realized measures.

Focusing on realized volatility is important in this study as it is a key element in financial market contagion. Moreover, Fleming, Kirby and Ostdiek (1998) demonstrate that the best way to look at information and information linkages in financial markets is through volatilities. More recently, Kenourgios, Samitas and Paltalidis (2010) have made use of dynamic conditional correlations to capture financial contagion. As noted by Kodres and Pritsker (2002), contagion occurs through a cross-market rebalancing channel - hence, when market participants are hit with a shock to idiosyncratic risk in one market (as measured by realized volatility in our study) the shock may be transmitted elsewhere by investors optimally rebalancing their portfolio exposures to macroeconomic risks (as captured by sovereign rating news). Chiang et al. (2007) reveal that sovereign credit rating changes significantly influence stock market correlations between Thailand and other 
Asian stock markets but our study differs by investigating the cross-asset market channel between stocks and currencies.

This paper complements existing studies yet makes several significant contributions to the academic literature on rating impacts in international financial markets (see for instance, Kaminsky and Schmukler (1999, 2002), Brooks et al. (2004), Gande and Parsely (2005), Chiang et al. (2007), Ferreira and Gama (2007)). First, to our best knowledge, this is the first study to apply intraday financial market data to assess the impact of sovereign credit ratings in financial markets. The advantages of using daily measures computed from intraday data over day to day closing prices is that they provide a better representation and more robust estimate of actual price behaviour. Daily close-toclose measures are unable to capture the intraday price fluctuations, which can be substantial particularly during times of financial distress. This is important given that this paper focuses on the impacts of different types of ratings information during financial crises. Moreover, Evans and Speight (2010) document that the reaction of foreign exchange returns to macroeconomic news is particularly fast. Second, we empirically investigate the volatility impacts of sovereign credit ratings and its spillover effects for the first time. Third, we document the differential impacts of ratings on currency markets and the cross-market relationship with stocks.

Overall, this research has important policy implications in light of the increased role of sovereign credit ratings under the current Basel banking regulatory framework. Moreover, this study is important because the significance of agency ratings information on asset prices has implications for the semi-strong form of market efficiency, which states that all public information should be immediately reflected in financial market prices. A clearer understanding of rating impacts on 
stock and currency markets will not only be beneficial for forecasting asset return volatility and risk management by corporate treasurers, portfolio investors and financial institutions managers but also system stability management by policymakers. The organization of this paper is as follows. In section 2, we provide the data description followed by the empirical modelling in Section 3. In Section 4 we discuss our findings before concluding in Section 5.

\section{Data description}

The dataset used in this study consists of the bid-ask quotes for both currencies traded and stock market indices in nine countries in the Asia-pacific region - namely, Australia, HK, Indonesia, Japan, Korea, Philippines, Singapore, Taiwan and Thailand. These are the only countries in the Asia-pacific region for which both stock and currency data are available at the intraday frequency. ${ }^{1}$ Our sample period starts 6 January 1997 and ends 30 August 2001.²

The FX data used in this paper consists of the tick-by-tick FX rates from Olsen and Associates (a proprietary international brokering firm) for the following currencies: Australian Dollar (AUD), Hong Kong Dollar (HKD), Indonesian Rupiah (IDR) Japanese Yen (JPY), Korean Won (KRW), Philippine Peso (PHP), Singaporean Dollar (SGD), New Taiwan Dollar (TWD) and Thai Baht (THB). All currencies are quoted against the USD. The most liquid FX rate in our sample is the JPY with the average number of quotes being 8,229 quotes in a 24 hour period (and 5,811 quotes

\footnotetext{
${ }^{1}$ Whilst data was also available for Malaysia, it was excluded from our sample due to the implementation of its currency control during the Asian Financial crisis. Bank Negara Malaysia pegged the ringgit to the U.S. dollar in September 1998, fixing its exchange rate at 3.80 ringgits to the dollar for almost seven years.

${ }^{2}$ The sample period that we study is the longest for which we have intraday data from both stock and currency markets to compute realized volatilities and cross market correlations
} 
during stock market trading hours) while the TWD is the least liquid rate with the average number of quotes being 98 quotes in a 24 hour period (and 77 quotes during stock market trading hours). The stock market index data are captured from the Reuters' terminal and provided by SIRCA (Securities Industry Research Centre of Asia) in their RDTH (Reuters DataScope Tick History - formerly TACTIQ) database. These indices include the Australian S\&P/ASX100 ${ }^{3}$ (ATO1), Hong Kong's Hang Seng Index (HSI), Jakarta Stock index (JSX), Japan Nikkei index (Nikkei), Korean KOSPI 200 Index (KS200), Philippine Composite Index (PCI), Singapore’s Strait Times Index (SSI), Taiwan Index (TWI) and the Stock Exchange of Thailand Index (SETI). All indices are denominated in local currencies. The SSI is the most liquid stock market index with the average number of quotes being 721 quotes a day while the TWI is the least liquid with the average number of quotes being 123 quotes a day. Although the FX market is a non-stop trading market, the stock market is not. Hence, when computing stock market realized measures and cross-stock-FX market correlations we only consider the part of the day when stock markets in these sample countries are open. Table A.1 shows stock market trading hours in our sample. We therefore define our trading hours for all stock markets considered as 23:00GMT to 09:00GMT, excluding weekends and 23:00 GMT to 23:00GMT for all FX markets.

In addition, we use the history of foreign currency sovereign credit ratings and credit outlooks and watches from Standard and Poors. ${ }^{4}$ As the timing of ratings

\footnotetext{
${ }^{3}$ As an alternative benchmark stock market index for Australia, we also analysed the All Ordinaries index and our conclusions remain qualitatively unchanged.

${ }^{4}$ We focus only on foreign currency sovereign ratings assessments provided by S\&P as previous studies have found these exert the greatest impact on market returns and are less anticipated (see Reisen and von Maltzan (1999) and Brooks et al. (2004)). Moreover, in comparing the ratings activity of S\&P, Moody’s and Fitch ratings during the Asian Financial crisis, Kaminsky and Schmukler (2002) revealed that S\&P was the most active in re-rating sovereigns but the three major rating agencies’
} 
announcements are not consistent ${ }^{5}$, we focus on daily impacts of ratings announcements. Consistent with standard practice in the sovereign ratings literature, we linearly transform actual ratings and outlook and credit watch guidance on imminent rating changes into a comprehensive credit rating (CCR) measure over time (Gande and Parsley (2005), Kim and Wu (2011)). The average CCR scores and revisions in sovereign credit ratings and outlook/credit watch guidance are summarised in Table 1 for each sample country and the chronology of S\&P's sovereign credit rating actions are detailed in Appendix Table A.2. There are a total of 53 rating events in our overall sample comprising 28 actual rating changes and 25 outlook/credit watch revisions. The bulk of these sovereign credit events occurred during the 1997-1998 Asian Financial Crisis when the credit assessments for Thailand, Indonesia, Korea, Phillippines and even Hong Kong were slashed. These lower rated countries in our sample were the most actively re-rated over the time period studied. Most notably, Indonesia was the only country to have been given a selective default (SD) rating during the $\mathrm{AFC}$ and it also incurred 11 rating changes and 6 outlook/watch revisions during and after the AFC.

$<$ insert Table 1>

Based on the works of Andersen and Bollerslev (1998), Barndorff-Nielsen \& Shephard (2001) and Andersen et al. (2003), we argue that daily realized measures calculated based on intraday returns provides more consistent and efficient measures than those computed from close to close prices.

Hence, the daily realized volatility is defined as follows:

$$
R V_{t}=\sum_{d=1}^{D} r_{d, t}^{2}
$$

sovereign ratings were fairly consistent for Asian countries during the 1997 - 1998 Asian Financial Crisis.

${ }^{5}$ S\&P ratings announcements are generally made local a.m. time but the exact timing is not consistent. 
where $r_{d, t}$ denotes a $d$ th 60 -minute return ${ }^{6}$ during day $t$ and $D$ denotes the total number of 60-minute return intervals during any trading day. ${ }^{7}$ This is the sum of consecutive squared log price changes.

The daily realized correlation is defined as follows:

$$
\operatorname{RCOR}_{t}=\sum_{d=1}^{D} \frac{\left(r_{d, j, t}-\bar{r}_{j, t}\right)\left(r_{d, i, t}-\bar{r}_{i, t}\right)}{\sigma_{i, t} \sigma_{j, t}}
$$

where $r_{d, i, t}$ and $r_{d, j, t}$ denote a $d$ th 60 -minute return during day $t$ for asset $i$ and $j ; \mathrm{s}_{\mathrm{i}, \mathrm{t}}$ and $\mathrm{s}_{\mathrm{j}, \mathrm{t}}$ are the standard deviations for asset $i$ and $j$ on day $t$; and $\bar{r}_{i, t}$ and $\bar{r}_{j, t}$ are the average returns for asset $i$ and $j$ on day $t$. Following Christiansen and Ranaldo's (2007) modelling of realized bond-stock correlation, we also perform a Fisher transformation to convert the $[-1,1]$ bounded correlation measure to support the whole real line.

Table 2 reports descriptive statistics of the daily realized volatilities and cross-market correlations. We find the Australian stock market index and the HKD to be the least volatile which makes intuitive sense given the strong economic performance of the former over the sample period and the latter is pegged at 7.8 HKD/USD under a currency board arrangement. Moreover, the Indonesian stock market index and the Philippine Peso are the most negatively skewed suggesting that they carried the greatest downside risk during the sample period. Most sample countries, except for Australia, Indonesia and Thailand, exhibit negative correlations

\footnotetext{
${ }^{6}$ The intraday return is calculated as the log difference of the midpoint at time $t$ and midpoint at time $t-1$. We use the mid-point quote between the Bid and Ask price to minimize the effect of Bid-Ask bounce, as suggested by Roll (1984).

${ }^{7}$ Based on volatility signature plots (available upon request), we proceeded to use the daily realized measures computed from 60 minute intervals for our empirical estimations as they appear to only stabilize from this sampling interval. As a robustness check, we also ran preliminary estimations with measures computed from higher frequency sampling intervals in the day. Our results remain qualitatively the same.
} 
between their stock and currency market returns. A strong serial correlation exists for daily realized series as the Ljung-Box Q-statistics rejects the null hypothesis of no autocorrelation up to twenty lags in most cases. The Augmented Dickey Fuller (ADF) test rejects the existence of a unit root in the time series of daily realized measures for both stock and FX markets. Hence, the time series of these daily realized measures can be analysed in levels.

$<$ insert Table 2>

\section{Empirical modeling}

To investigate the impacts of ratings announcements on realized volatilities and cross-market correlations for currency and stock returns, we utilise a framework similar to that adopted by Christiansen and Ranaldo (2007) for studying intraday news effects in the US stock and bond markets.

However, instead of using straight-forward dummy or indicator variables for capturing announcement effects during the trading day, we adopt the numerical credit rating "event" variables similar to those used in Gande and Parsely (2005) and Ferreira and Gama (2007) for studying rating spillover effects from other countries in international debt and stock markets respectively. In this way, we introduce a more flexible framework for investigating the impact of different types of ratings information on the day of announcement.

Rating 'events' are defined as a non-zero change in the linearised comprehensive credit rating series for actual credit ratings and credit outlooks and watches assigned to the country’s sovereign debt (following Gande and Parsley, 2005). Both forms of ratings guidance (ratings and outlooks) are intended to be forwardlooking measures of the perceived ability and willingness of sovereign debt issuers to service their financial obligation. However, actual rating changes reflect perceived 
permanent changes in credit quality in the long-term whereas credit outlooks and watches indicate imminent changes in ratings over the short-term.

We are aware that there may potentially be an endogenous relationship between sovereign ratings and the second moments of asset returns. However, in preliminary granger causality tests, we ascertain that in the majority of cases, there is only unidirectional causality from sovereign ratings to the realized measures. ${ }^{8}$ Guided by this we proceed to use pooled (panel) regressions to estimate the following base model specification with fixed country effects:

$$
Y_{i, t}=\alpha_{i}+\beta_{1} \text { Event }_{i, t}+\beta_{2} \text { Event }_{i, t-1}+\beta_{3} C C R_{i, t}+\sum_{k=4} \beta_{K} X+\varepsilon_{i, t}
$$

where $Y_{i, t}$ is the realized volatility; or cross-FX-stock return correlation for country i on day t, $\mathrm{CCR}_{\mathrm{i}, \mathrm{t}}$ is the country's comprehensive credit ratings level, Event $\mathrm{i}_{\mathrm{i}, \mathrm{t}}$ is the nonzero change in the CCR measure on day $t$ and $\mathrm{X}$ is a matrix of variables relating to different types of ratings information and periods of financial crises (Asian Financial crisis - AFC and Emerging market financial crises - EMFC which is the sum of the AFC, Russian as well as the Brazilian and Turkish financial crises occurring during our sample period) and $\varepsilon_{i, t}$ is a random error term. ${ }^{9,10}$ The main variables of interest are Event and other rating and crises variables (modelled as intercept and/or interactive dummy variables).

\footnotetext{
${ }^{8}$ These preliminary granger causality test results are available upon request.

${ }^{9}$ The financial crises variables are defined with a value of one on days during international financial crises and zero otherwise based on dates in Kaminsky and Schmukler (2002) and Kaminsky et al. (2003).

${ }^{10}$ Dynamic panel data estimations with $\Delta \mathrm{Y}$ and $\mathrm{Y}_{\mathrm{t}-1}$ were also conducted but the model specification was not appropriate. Furthermore, we also included $\mathrm{Y}_{\mathrm{t}-1}$ as an additional explanatory variable to account for serial correlation and used $\log \left(\mathrm{Y}_{\mathrm{t}}\right)$ as the dependent variable but the conclusions remain virtually unchanged and have been omitted for brevity.
} 
This empirical framework is sufficiently flexible to allow for an in-depth analysis on the market impacts of different types of ratings information - downgrades and upgrades; outlook and rating changes; investment grade rating; rating spillovers and their interaction with financial crises and national market attributes. We adopt a similar regression model specification to that used in Ferreira and Gama (2007) to capture the form of rating impacts. However, we uniquely depart from their event study methodology used to study rating spill over effects in international stock market returns by using higher frequency data to study rating impacts on financial market stability as measured by more efficient and consistent daily realized volatility and correlation measures and focusing on same country rating impacts in addition to rating spill over effects. Furthermore, we broaden our ratings study to assess the impact of different types of ratings information on financial market stability, with a particular focus on periods of financial crises.

We first compare the impact of region specific and generic emerging market financial crises on realized volatilities and correlations in Asia-pacific financial markets with two intercept dummy variables that take on values of one during either the Asian financial crisis (AFC) or throughout all emerging market financial crises (EMFC) occurring in the sample.

$$
Y_{i, t}=\alpha_{i}+\beta_{1} \text { Event }_{i, t}+\beta_{2} \text { Event }_{i, t-1}+\beta_{3} C C R_{i, t}+\beta_{4} A F C_{t}+\beta_{5} E M F C_{t}+\varepsilon_{i, t}
$$

Second, to separately compare the impact of downgrade and upgrade phases in ratings and their interactive effects with financial crises the following models are estimated:

$$
\begin{aligned}
& Y_{i, t}=\alpha_{i}+\beta_{1} \text { Event }_{i, t}+\beta_{2} \text { Event }_{i, t-1}+\beta_{3} \text { CCR }_{i, t}+\beta_{4} I_{i, t}+\varepsilon_{i, t} \\
& Y_{i, t}=\alpha_{i}+\beta_{1} \text { Event }_{i, t}+\beta_{2} \text { Event }_{i, t-1}+\beta_{3} C C R_{i, t}+\beta_{4} \text { AFC }_{t}+\beta_{5} \text { AFC }_{t} \times I_{i, t}+\varepsilon_{i, t}
\end{aligned}
$$


where $I_{t}$ is an indicator variable for downgrades - DG (upgrades - UG) and takes a value of one in the period from a negative (positive) to positive (negative) rating event and zero otherwise. The bulk of existing rating studies find that rating downgrades have more significant impact on market returns than upgrades (see for example, Brooks et al. (2004) and Creighton et al. (2007)). However, unlike the existing event studies in the literature, we attempt to capture the longer-term significance of DG and UG phases instead of events on stock and currency markets.

Third, to identify the potential differential market reactions to outlook and rating changes, the following models are estimated:

$$
\begin{aligned}
& Y_{i, t}=\alpha_{i}+\beta_{1} \text { event }_{i, t}+\beta_{2} \text { event }_{i, t-1}+\beta_{3} \text { CCR }_{i, t} \\
& +\beta_{4} \text { Outch }_{i, t} \times I_{i, t}+\beta_{5} \text { Ratch }_{i, t} \times I_{i, t}+\varepsilon_{i, t} \\
& Y_{i, t}=\alpha_{i}+\beta_{1} \text { event }_{i, t}+\beta_{2} \text { event }_{i, t-1}+\beta_{3} \text { CCR }_{i, t}+\beta_{4} \text { AFC }_{t} \\
& +\beta_{5} \text { Outch }_{i, t} \times I_{i, t} \times \text { AFC }_{t}+\beta_{6} \text { Ratch }_{i, t} \times I_{i, t} \times \text { AFC }_{t}+\varepsilon_{i, t}
\end{aligned}
$$

where Outch $\mathrm{t}_{\mathrm{t}}$ is a dummy variable defined as one when there is a change in sovereign outlook or credit watch and zero otherwise and Ratch $\mathrm{t}_{\mathrm{t}}$ is similarly defined for actual ratings changes. Both of these variables are then interacted with the DG/UG indicator variables and/or the AFC to compare the separate impacts of positive and negative outlook and actual rating events and their influence on financial market stability during financial crises.

Fourth, to explore the behaviour of investment grade countries we estimate the following model specification:

$$
\begin{aligned}
& Y_{i, t}=\alpha_{i}+\beta_{1} \text { Event }_{i, t}+\beta_{2} \text { Event }_{i, t-1}+\beta_{3} \text { CCR }_{i, t}+\beta_{4} \text { AFC }_{t} \\
& +\beta_{5} I N V_{i, t}+\beta_{6} I N V_{i, t} \times A F C_{t}+\varepsilon_{i, t}
\end{aligned}
$$

Fifth, we test whether national attributes like the countries' development status, legal origin, exchange rate regime and ASEAN (trade bloc) membership influences the impact that sovereign ratings have on stock and currency markets under 
crises conditions. We model the interactive effects of these country-level attributes during a financial crisis in the following specification:

$$
\begin{aligned}
& Y_{i, t}=\alpha_{i}+\beta_{1} \text { Event }_{i, t}+\beta_{2} \text { Event }_{i, t-1}+\beta_{3} \text { CCR }_{i, t}+\beta_{4} \text { AFC }_{t} \\
& +\sum_{M=5} \beta_{M} M \times \text { AFC }_{t} \times \text { Event }_{i, t}+\varepsilon_{i, t}
\end{aligned}
$$

where $\mathrm{M}$ is a matrix of four national attribute variables: Emerg which equals one for emerging market countries based on membership in the MSCI emerging stock market index (and zero otherwise); Leg_orig which equals one for common law countries based on the classification of La Porta et al. (1997, 1998) (and zero otherwise); $E x \_r e g$ which equals to one for countries with floating exchange rate systems based on the IMF's annual report on exchange arrangement and exchange restrictions (and zero otherwise) and Asean which equals to one for countries that are members of the Association for South Eastern Asian Nations (and zero otherwise).

Finally, in the spirit of Gande and Parsley (2005) and Ferreira and Gama’s (2007) ratings spillover studies we also sequentially replace the national ratings Event variable for country $\mathrm{j}$ with all other countries' rating events to determine the rating spillover effects from other sample countries' stock and currency markets in the Asiapacific region. Hence, the following model specification was also estimated:

$$
Y_{j, t}=\alpha_{i}+\beta_{1} \text { Event }_{i, t}+\beta_{2} \text { Event }_{i, t-1}+\beta_{3} C C R_{i, t}+\beta_{4} C C R_{j, t}+\sum \beta_{K, j} X_{K, j, t}+\varepsilon_{j, t} \forall j \notin i
$$

\section{Findings}

\subsection{Rating impacts on realized volatilities}

Tables 3 and 4 report estimates of the panel regression models in Eq. (4-8) for realized stock and currency market volatilities respectively. We find evidence that ratings events within a country have significant impacts on both stock and FX markets but the effects are less significant in the latter. Moreover, realized volatility reacts 
inversely on the day of the rating event suggesting that rating downgrades have greater 'news' effects in Asia-Pacific financial markets. Moreover, consistent with rating impacts in other financial studies (Reisen and Von Maltzan (1999), Brooks et al. (2004), Gande and Parsely (2005), Ferreira and Gama (2007)) realized volatility in both stock and FX markets exhibits asymmetric responses in that the impact on realized volatility is positive and generally of a larger magnitude in phases following rating downgrades and is negative during upgrades. However, during the AFC only downgrade phases worked to raise realized volatility in Asian stock markets. This suggests that ratings downgrade news are particularly destabilizing for stock markets during financial crises. The less significant reactions in FX markets suggest that stock market participants may pay more attention to a country’s sovereign ratings guidance than currency market participants, especially in times of financial turmoil.

$<$ insert Tables 3 and $4>$

Realized volatility in both stock and currency markets were significantly and positively affected by both the region specific Asian financial crisis (AFC) and Emerging market financial crises (EMFC). As expected, the region specific AFC had a greater impact than generic EMFC as evidenced by the larger magnitude of the AFC coefficient. Significant positive coefficients for the interaction between the AFC and downgrade and upgrade indicator variables show that realized volatilities were indeed significantly heightened during the AFC consistent with Chakrabarti and Roll’s (2002) finding of structural increases in stock market volatilities during the AFC.

In comparing the impacts of upgrades and downgrades in outlook changes and actual rating changes (Eq. (6a,b)), we find that both upgrade outlook and rating changes significantly affect stock and FX market realized volatilities at the 5\% level of significance in the expected direction but only downgrade outlook changes are 
significant for stock market stability and downgrade rating changes are significant for the FX market. This suggests that the more forward-looking and shorter-term types of ratings guidance in the form of outlooks and credit watches on sovereign obligors are perceived to have more informational value for stock market participants than permanent rating changes. This is possibly because rating changes (especially downgrades) are often already anticipated by market participants as they are usually preceded by negative outlooks and credit watches (Gande and Parsley (2004)). This finding is consistent with both Larrain et al.’s (1997) earlier finding that sovereign ratings have a particularly significant announcement effect on debt spreads when countries are given a negative outlook and Kaminsky and Schmukler's (2002) comparison of outlook and rating effects on debt spreads and stock market returns.

During the AFC, there were heterogeneous impacts on realized volatility in stock and FX markets. In stock markets, only outlook changes increased realized volatility. Again, this could be because rating changes are often already anticipated by stock market participants. However, in FX markets both rating and outlook changes were important suggesting that FX market participants value both types of ratings assessments. The market reaction to sovereign ratings information is consistent with revelations of market efficiency in Asian financial markets (see for example, Chiang et al., 2010).

As expected, we find that countries with investment grade ratings during the Asian financial crisis had significantly lower realized volatilities in both their stock and FX markets.

Finally, we also find that national attributes play a significant role on both stock and FX market volatilities during financial crises. Consistent with the law and finance literature (eg. La Porta et al. (1997, 1998)), we find that common law 
countries have lower stock market volatilities during financial crises than civil law countries. According to Ergungor (2004), countries with English legal origin tend to be more adaptable to incomplete contracts and are more effective in resolving conflicts because the system is more flexible in interpreting the laws and creating new rules. As a result, the common law courts provide better creditor and investor protection than civil ones.

We find that during financial crises, FX market stability is more sensitive to national market attributes than stock market stability. In addition, to legal origin, FX realized volatilities are also lower in ASEAN members and countries with floating exchange rate regimes but higher in emerging markets.

\subsection{Rating impacts on realized stock-currency correlation}

Table 5 presents the panel estimation results for realized correlations across same country stock and currency market returns (Eq. 4-8). As can be seen, there is an insignificant relationship between generic rating events and cross-stock-FX correlations. However, there are significant asymmetric impacts from outlook changes. Negative outlooks work to increase cross-asset correlations whilst positive outlooks reduce realized correlations at the $10 \%$ level of significance. This suggests that market participants in both asset markets heed a bad outlook regarding the country in the same manner but not so for good outlooks. A negative outlook signals deterioration in the country's future economic conditions and induces similar effects on its stock and currency markets. Consistent with the existing literature, outlook changes do have greater impacts on asset returns than actual rating changes.

$$
<\text { insert Table 5> }
$$

Interestingly, we also find that cross-asset market correlations within the Asia-Pacific region are not significantly different during financial crises. This country 
sample is different to those used by other studies finding strengthened relationships between stock and currency returns as a result of the AFC (for example, Kallberg et al. (2005), Phylaktis and Ravazzolo (2005) and Cumperayot et al. (2006) amongst others) and provides intraday evidence that cross-stock-FX market contagion does not necessarily increase during financial turmoil due to heterogeneous impacts on underlying stock and currency market volatilities. Whilst Kaminsky and Schmukler (2002) conclude that sovereign ratings generate cross-country financial contagion, we find that rating impacts are no more pronounced on same country cross-asset market comovements during periods of financial turmoil. This is a new finding for the current literatures on stock and currency market relations and rating impacts.

For realized correlation estimations, we introduce a high volatility indicator variable (high_vol) to account for periods of high market volatility and the welldocumented 'volatility in correlation effect'. Forbes and Rigobon (2002) argue that high volatility naturally leads to high correlations in asset returns. Hence our high volatility indicator variable takes on a value of one on days when stock market volatility is greater than the median and zero otherwise. ${ }^{11}$ As expected, the estimated coefficient is positive in all estimations. However, as this indicator variable is naturally highly correlated with the AFC dummy, we do not include an additional AFC intercept dummy along with interaction terms.

Furthermore, we show that realized stock-FX correlations associated with investment grade ratings are lower during normal market conditions but the investment grade ratings did not significantly alter cross-asset market correlations during the AFC. We can interpret this finding as stock and currency market

\footnotetext{
${ }^{11}$ We find that a stock market volatility indicator is much more significant than a fx volatility indicator for the stock-fx correlation.
} 
participants treating investment grade and junk countries in a similar fashion when a crisis hits.

We find that cross-stock-FX market correlations are significantly related to national market attributes during financial crises. Legal origin is highly significant at the $1 \%$ level. In common law countries, cross-market correlations during a financial crisis are reduced suggesting that stock and currency markets are more stable in common law and civil law countries during periods of financial turmoil. Similarly, stock-FX correlations are also lower in emerging countries with floating exchange rate regimes and in ASEAN members. Based on above results, these national market attributes appear to be more influential on FX markets than stock markets and have the overall effect of stabilizing instabilities across stock and FX markets during financial crises.

\subsection{Rating spillover effects}

Table 6 presents the panel estimation results for Eq. (9). We find that within our sample, there were only rating spillover effects from Indonesia, the Philippines and Thailand to the other stock and FX markets in the Asia-pacific region. ${ }^{12}$ We find evidence that realized volatility in stock and FX markets were marginally responsive to rating spillover effects from these three countries. This suggests that speculative grade countries (being Indonesia and Philippines) imparted the strongest rating spillover effects alongside Thailand which was at the heart of the AFC.

It should be noted that the market impact of ratings spillovers are economically and statistically less significant than the own country rating effects discussed above. These findings suggest that whilst the ratings events of advanced

\footnotetext{
${ }^{12}$ As such, only rating spillover results from Indonesia, Philippines and Thailand are presented for brevity.
} 
markets in the Asia-pacific are generally interpreted by market participants as country-specific news, there were common information spillovers from the more troubled economies into the other Asian markets. As the sovereign rating performance of the contagious countries declined, the perception of riskiness in other Asian markets also increased, leading to increased realized volatilities in stock and FX markets. The AFC also significantly heightened the rating spillover effects on realized volatilities of stock and currency markets and influenced cross-market correlations in other sample countries. This corroborates with Kaminsky and Schmukler's (1999, 2002) finding that a country’s sovereign ratings news is one channel through which financial crises may spread. Furthermore, it is conceivable that ratings changes affect trading volume and the volume effects spillover to cross-border return and volatility processes consistent with the findings of Hussain (2011).

In line with the work of Ferreira and Gama (2007), national market attributes are also shown to have significant influences on the extent of rating spill over effects during financial crises. In emerging markets, we find that rating events for Indonesia and the Philippines worked to heighten stock market volatilities in other pacific countries but not FX market volatilities. Rating events for the Philippines and Indonesia also increased cross-asset market correlations in other emerging markets. We find legal origin to have the greatest influence on rating spillovers during the AFC. In common law countries, Indonesia and Philippines' rating events during the financial crisis also increased stock market instability in the group and rating events from Indonesia and Thailand unanimously exacerbated financial market volatilities in other common law countries' FX markets as well. We conjecture this is due to the fact that common law is based on judges' discretion in interpreting and applying the law and this may cause greater uncertainty in financial outcomes. Yet, there is evidence in 
our rating spill over results to suggest that cross-market correlations remained lower in common law countries despite significant rating spillover events. In markets with floating exchange rate systems and membership in the ASEAN trade bloc, we find that rating spillovers from Indonesia and the Philippines served to dampen stock and FX market volatilities. However, rating events from Thailand had a clear destabilizing effect on other FX markets in these groupings.

$<$ insert Table 6>

\section{Conclusions}

We examine the effects of different sovereign rating announcements and its spillover effects on stock and currency markets in the Asia-Pacific region around the Asian Financial Crisis. We study the period from 1997-2001, using ratings history from Standard and Poors, the longest established ratings agency.

We find that currency and stock markets react somewhat differently to ratings announcements with stock markets being statistically more responsive to rating news than currency markets. Changes on sovereign credit outlooks have more significant impact on stock market realized volatilities than actual rating changes. We find clear evidence that rating events have significant and asymmetric impacts on the second moments of both asset market returns during normal market conditions as downgrades (upgrades) increase (decrease) realized volatilities. Realized stock-FX correlations increase with downgrades and decline with upgrades and this asymmetry does not change during financial crises. The AFC served to increase the sensitivity of realized volatilities and correlations to different types of ratings information and the influence of national market attributes, thereby heightening financial market instability. Finally, there were marginal rating spillover effects from Indonesia, Philippines and Thailand on other markets' realized measures. More developed and 
stable financial markets are less inclined to impart rating spillover effects into other asset markets in the region.

In a period where credit rating agencies are increasingly placed under the spotlight due to a new international banking regulatory framework and their failures to provide early warnings on financial crises, our findings are especially insightful. Our results provide clear evidence that rating announcements are heeded by market participants and consequently have significant impacts on financial market stability, albeit to differing extents across asset markets and in times of financial crises.

In summary, we find new evidence that national sovereign rating events have significant impacts on the second moments of stock and currency returns. Future research into the impacts of credit ratings on international financial markets need to recognize and account for this to fully capture the true extent of rating influence on asset returns. Our findings have important implications for international policy makers, financial market participants and corporate managers of multinational firms. 


\section{References}

Andersen, T. G., Bollerslev, T., 1998. Answering the skeptics: Yes, standard volatility models do provide accurate forecasts. International Economic Review 39(4), 885-905. Andersen, T., Bollerslev, T., Diebold, F., Labys, P., 2003. Modeling and Forecasting Realized Volatility, Econometrica 71(2), 579-625.

Barndorff-Niesen, O. E., Shephard, N., 2001. Non-Gaussian Ornstein - Uhlenbeck based models and some of their uses in financial economics. Journal of the Royal Statistical Society, Series B 63, 167-241.

Brooks, R., Faff, R., Hillier, D., Hillier, J., 2004. The national market impact of sovereign rating changes. Journal of Banking and Finance 28, 233-250.

Chakrabati, R., Roll, R., 2002. East Asia and Europe during the 1997 Asian collapse: a clinical study of a financial crisis, Journal of Financial Markets 5, 1-30.

Chiang, S-M., Lee, Y-H., Su, H-M., Tzou, Y-P., 2010. Efficiency tests of foreign exchange markets for four Asian countries. Research in International business and Finance 24(3), 284-294.

Chiang, T.C., Jeon, B.N., Li H., 2007. Dynamic correlation analysis of financial contagion: Evidence from Asian markets, Journal of International Money and Finance 26, 1206-1228.

Christiansen, C., Ranaldo, A., 2007. Realized bond-stock correlation: Macroeconomic Announcement effects, Journal of Futures Markets 27(5), 439-469.

Creighton, A., Gower, L., Richards, A.J., 2007. The impact of rating changes in Australian financial markets. Pacific-Basin Finance Journal 15, 1-17.

Cumperayot, P., Keijzer, T., Kouwenberg, R., 2006. Linkages between extreme stock market and currency returns, Journal of International Money and Finance, 25, 528550. 
Ergungor, O.E., 2004. Market- vs. bank-based financial systems: Do rights and regulations really matter? Journal of Banking and Finance 28 (12), 2869-2887.

Evans, K, Speight, A., 2010. Dynamic news effects in high frequency euro exchange rates. Journal of International Financial Markets, Institutions and Money 20, 238-258. Ferreira, M.A., Gama, P.M., 2007. Does sovereign debt ratings news spill over to international stock markets? Journal of Banking and Finance 31, 3162-3182.

Ferri, G., Liu, L., Stiglitz, J., 1999. The procyclical role of rating agencies: Evidence from the East Asian crisis. Economic notes, 28(3), 335-355.

Fleming, J., Kirby, C., Ostdiek, B., 1998. Information and volume linkages in the stock, bond and money markets, Journal of Financial Economics 49, 111-137.

Gande, A., Parsley, D.C., 2005. News spillovers in the sovereign debt market. Journal of Financial Economics 75, 691-734.

Hussain, S-M., 2011. Intraday trading volume and international spillover effects.

Research in International business and Finance 25(2), 183-194.

Kallberg, J.G., 2005. An examination of the Asian crisis: Regime shifts in currency and equity markets. Journal of Business 78, 169-211.

Kaminsky, G., Reinhart, G., Vegh, C., 2003. The unholy trinity of financial contagion. Journal of Economic Perspectives 17, 51-74.

Kaminsky, G., Schmukler S.L, 2002. Emerging market instability: Do sovereign ratings affect country risk and stock returns? World Bank Economic Review 16(2), 171-195.

Kaminsky G, Schmukler S.L, 1999. What triggers market jitters? A chronicle of the Asian crisis, Journal of International Money and Finance 18, 537-560. 
Kenourgios, D., Samitas, A, Paltalidis, N., 2010. Financial crises and stock market contagion in a multivariate time-varying asymmetric framework, Journal of International Financial Markets, Institutions and Money 21, 92-106.

Kim, S-J., 2003. The spillover effects of U.S. and Japanese public information news in advanced Asia-Pacific stock markets, Pacific Basin Finance Journal 11, 611-630.

Kim, S-J, Wu, E., 2011. International bank flows to emerging markets: Influence of sovereign credit ratings and their regional spillover effects', Journal of Financial Research, 34(2), 331-365.

Kodres, L., Pritsker, M., 2002. A rational expectations model of financial contagion, Journal of Finance 57, 769-799.

La Porta, R., Lopez-de-Silanes, F., Shleifer, A., Vishny R.W., 1997. Legal determinants of external finance, Journal of Finance 52, 1131-1150.

La Porta, R., Lopez-de-Silanes, F., Shleifer, A., Vishny R.W., 1998. Law and Finance, Journal of Political Economy 106, 1113-1155.

Larrain, G., Reisen, H., von Maltzan, J., 1997. Emerging market risk and sovereign credit ratings. OECD Development Centres, Technical Papers No. 124.

Phylaktis, K., Ravazzolo, F., 2005. Stock prices and exchange rate dynamics. Journal of International Money and Finance 24, 1021-1053.

Reisen, H., Von Maltzan, 1999. Boom and bust and sovereign ratings. International Finance 2, 273-293.

Roll, R., 1984. An implicit measure of the bid-ask spread in an efficient market. Journal of Finance, 39, 1127-1139. 
Figure 1. Stock and Fx realized volatilities and rating event dates for Thailand and Korea during the Asian Financial Crisis

This figure shows the rating event dates (in red) and the daily realized volatilities for stock and foreign exchange markets (in blue) for Thailand and Korea - two of the most affected countries during the Asian financial crisis period.

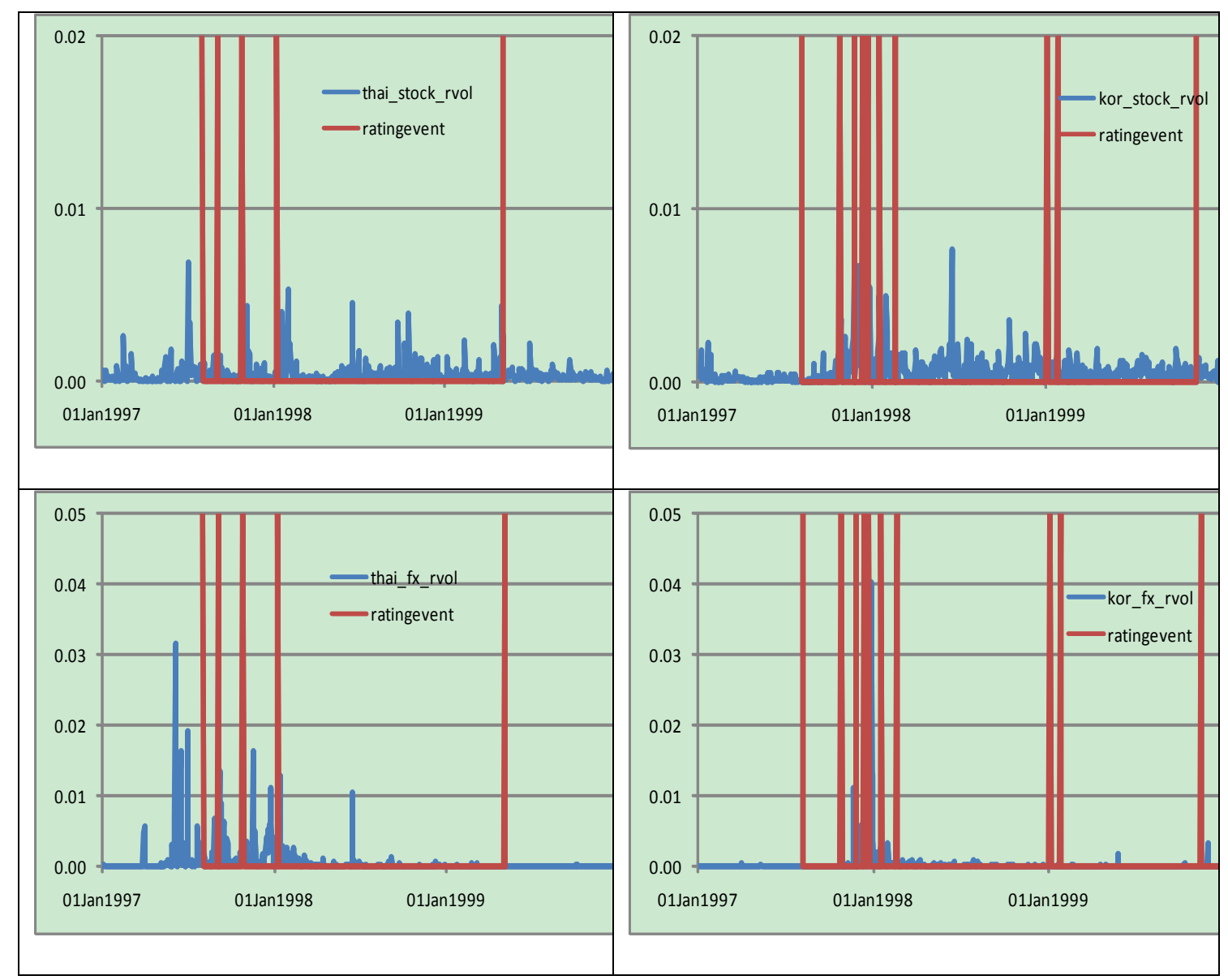


Table 1. Summary of sovereign credit rating assessments by country for the sample period from 6 January 1997 to 30 August 2001

\begin{tabular}{|c|c|c|c|c|c|c|}
\hline & Average rating score (rating) & Rating Range & Average Investment Grade & Rating changes & Outlook changes & \\
\hline SGP & 20 (AAA) & (AAA, AAA) & Investment grade & 0 & 0 & \\
\hline JAP & 19.9 (AAA) & $(\mathrm{AAA}, \mathrm{AA}+)$ & Investment grade & 1 & 0 & \\
\hline TAI & $19(\mathrm{AA}+)$ & $(\mathrm{AA}+, \mathrm{AA})$ & Investment grade & 1 & 1 & \\
\hline AUS & $18.5(\mathrm{AA} / \mathrm{AA}+)$ & $(\mathrm{AA}+, \mathrm{AA})$ & Investment grade & 1 & 1 & \\
\hline $\mathrm{HK}$ & $15.3(\mathrm{~A})$ & $(A+, A)$ & Investment grade & 3 & 4 & \\
\hline KOR & $13.4(\mathrm{BBB}+)$ & $(\mathrm{AA}-, \mathrm{B}+)$ & Investment grade & 7 & 5 & \\
\hline THA & $12.2(\mathrm{BBB})$ & (A, BBB-) & Investment grade & 3 & 3 & \\
\hline PHI & $9.6(\mathrm{BB}+)$ & $(\mathrm{BB}+, \mathrm{BB})$ & Speculative grade & 1 & 4 & \\
\hline INDO & $6.5(\mathrm{~B} / \mathrm{B}+)$ & $(\mathrm{BBB}, \mathrm{SD})$ & Speculative grade & 11 & 6 & \\
\hline & & & Total & 28 & 24 & 52 \\
\hline
\end{tabular}


Table 2. Descriptive statistics

\begin{tabular}{|c|c|c|c|c|c|}
\hline & RV-stocks & RV-FX & RS-stocks & RS-FX & RC-stocks-FX \\
\hline \multicolumn{6}{|l|}{ AUS } \\
\hline Mean & 0.0600 & 0.0700 & -0.11585 & 0.05689 & 0.01005 \\
\hline $\mathrm{Q}(20)$ & $268.86 * * *$ & $876.27 * * *$ & 19.609 & 28.207 & 26.307 \\
\hline $\mathrm{ADF}$ & $-14.730 * * *$ & $-12.678 * * *$ & $-32.585 * * *$ & $-33.806 * * *$ & $-32.086 * * *$ \\
\hline \multicolumn{6}{|l|}{ HK } \\
\hline Mean & 0.2900 & 0.0001 & -0.00459 & -0.08671 & -0.00419 \\
\hline $\mathrm{Q}(20)$ & $908.4^{* * *}$ & $995.65 * * *$ & 62.725 & 24.308 & $41.891 * *$ \\
\hline ADF & $-10.490 * * *$ & $-8.997 * * *$ & $-30.019 * * *$ & $-36.045 * * *$ & $-34.388 * * *$ \\
\hline \multicolumn{6}{|l|}{ INDO } \\
\hline Mean & 0.3570 & 3.099 & -0.20510 & -0.07094 & 0.00139 \\
\hline $\mathrm{Q}(20)$ & $422.14 * * *$ & $2352.86 * * *$ & $107.44^{* * *}$ & 25.463 & $35.141 * *$ \\
\hline ADF & $-11.002 * * *$ & $-3.491732 * * *$ & $-28.432 * * *$ & $-35.195 * * *$ & $-32.214^{* * *}$ \\
\hline \multicolumn{6}{|l|}{ JAP } \\
\hline Mean & 0.1800 & 0.0693 & -0.01581 & -0.04595 & -0.05236 \\
\hline $\mathrm{Q}(20)$ & $698.87 * * *$ & $1691.2^{* * *}$ & 22.588 & 13.296 & $99.836 * * *$ \\
\hline ADF & $-9.718 * * *$ & $-7.444 * * *$ & $-33.522 * * *$ & $-37.050 * * *$ & $-16.577 * * *$ \\
\hline \multicolumn{6}{|l|}{ KOR } \\
\hline Mean & 0.6100 & 0.0100 & -0.05852 & 0.06202 & -0.07246 \\
\hline $\mathrm{Q}(20)$ & $1026.7 * * *$ & $2969 * * *$ & $108.33^{* * *}$ & $34.282 * *$ & $44.468 * * *$ \\
\hline $\mathrm{ADF}$ & $-9.228 * * *$ & $-4.923 * * *$ & $-27.406^{* * *}$ & $-31.357 * * *$ & $-33.813^{* * *}$ \\
\hline \multicolumn{6}{|l|}{ PHI } \\
\hline Mean & 0.2870 & 0.3400 & 0.05779 & -0.09064 & -0.03759 \\
\hline $\mathrm{Q}(20)$ & $268.67 * * *$ & $1363.8 * * *$ & $61.431^{* * *}$ & 21.350 & 16.367 \\
\hline $\mathrm{ADF}$ & $-14.319 * * *$ & $-6.221 * * *$ & $-28.447 * * *$ & $-35.818 * * *$ & $-35.633^{* * *}$ \\
\hline \multicolumn{6}{|l|}{ SGP } \\
\hline Mean & 0.2100 & 0.0311 & 0.02877 & -0.02431 & -0.00391 \\
\hline $\mathrm{Q}(20)$ & $500.31 * * *$ & $2093.4^{* * *}$ & $35.597 * *$ & $29.086^{*}$ & 8.8943 \\
\hline $\mathrm{ADF}$ & $-10.728 * * *$ & $-5.741 * * *$ & $-30.339 * * *$ & $-34.537 * * *$ & $-34.914 * * *$ \\
\hline \multicolumn{6}{|l|}{ TAI } \\
\hline Mean & 0.2780 & 0.0151 & -0.11173 & 0.19630 & -0.06338 \\
\hline $\mathrm{Q}(20)$ & $686.62 * * *$ & $673.14 * * *$ & $157.59 * * *$ & $74.510 * * *$ & $34.913^{* *}$ \\
\hline $\mathrm{ADF}$ & $-9.955 * * *$ & $-21.077 * * *$ & $-19.303^{* * *}$ & $-33.821^{* * *}$ & $-33.259 * * *$ \\
\hline \multicolumn{6}{|l|}{ THA } \\
\hline Mean & 0.3590 & 0.5900 & 0.09720 & -0.05280 & 0.01061 \\
\hline $\mathrm{Q}(20)$ & $488.46 * * *$ & $2171.9 * * *$ & $56.452 * * *$ & $36.542^{* *}$ & 8.605 \\
\hline $\mathrm{ADF}$ & $-13.082 * * *$ & $-5.973 * * *$ & $-30.259 * * *$ & $-26.692 * * *$ & $-33.413 * * *$ \\
\hline
\end{tabular}

This table reports the average values for stock and currency market realized volatilities, skewness and cross-market correlations. The Q(20) statistics are for the Ljung-Box Q test for serial correlation up to 20 lags. The ADF test is for the null hypothesis of a unit root and the critical value at the $1 \%$ level of significance is $3.44 . *{ }^{* *}$ and $* * *$ denote significance at the 10,5 and $1 \%$ levels. 
Table 3. Impact of different types of sovereign ratings on stock market realized volatility in financial crises

\begin{tabular}{|c|c|c|c|c|c|c|c|c|}
\hline STOCK VOL & (1) & (2) & (3) & (4) & (5) & (6) & (7) & (8) \\
\hline \multirow[t]{2}{*}{ Const } & 0.8903 & $2.875^{* * *}$ & $1.607^{*}$ & 1.021 & $1.455^{*}$ & 1.044 & 1.203 & $0.2888 * * *$ \\
\hline & $\{0.2925\}$ & $\{0.0001\}$ & $\{0.0561\}$ & $\{0.2237\}$ & $\{0.0802\}$ & $\{0.2124\}$ & $\{0.1273\}$ & $\{0.0001\}$ \\
\hline \multirow[t]{2}{*}{ Event } & $-1.262 * *$ & $-1.217^{* *}$ & $-1.138 * *$ & $-1.278 * *$ & $-1.273^{* *}$ & $-1.287 * *$ & $-1.226^{* *}$ & $-0.1108^{*}$ \\
\hline & $\{0.0255\}$ & $\{0.0390\}$ & $\{0.0461\}$ & $\{0.0251\}$ & $\{0.0224\}$ & $\{0.0244\}$ & $\{0.0308\}$ & $\{0.0554\}$ \\
\hline \multirow[t]{2}{*}{ Lag Event } & -0.6125 & -0.5667 & -0.488 & -0.6276 & -0.6230 & -0.6372 & -0.5755 & -0.0567 \\
\hline & $\{0.3149\}$ & $\{0.3604\}$ & $\{0.4230\}$ & $\{0.3038\}$ & $\{0.3234\}$ & $\{0.2970\}$ & $\{0.3572\}$ & $\{0.3602\}$ \\
\hline \multirow[t]{2}{*}{ CCR } & $0.1410 * *$ & -0.0127 & $0.1025^{*}$ & $0.1270 * *$ & $0.1068^{*}$ & $0.1255^{* *}$ & $0.1765 * * *$ & -0.0014 \\
\hline & $\{0.0164\}$ & $\{0.8024\}$ & $\{0.0778\}$ & $\{0.0287\}$ & $\{0.0654\}$ & $\{0.0303\}$ & $\{0.0041\}$ & $\{0.7893\}$ \\
\hline \multirow[t]{2}{*}{ AFC } & & $2.278 * * *$ & & $1.680 * * *$ & & $1.680^{* * *}$ & $3.360 * * *$ & $0.2270 * * *$ \\
\hline & & $\{0.0000\}$ & & $\{0.0000\}$ & & $\{0.0000\}$ & $\{0.0005\}$ & $\{0.0000\}$ \\
\hline \multirow{2}{*}{ EMFC } & & $0.8845^{* * *}$ & & & & & & \\
\hline & & $\{0.0000\}$ & & & & & & \\
\hline \multirow[t]{2}{*}{ DG } & & & $1.482 * * *$ & & & & & \\
\hline & & & $\{0.0000\}$ & & & & & \\
\hline \multirow[t]{3}{*}{ UG } & & & - & & & & & \\
\hline & & & $0.4616 * * *$ & & & & & \\
\hline & & & $\{0.0024\}$ & & & & & \\
\hline \multirow[t]{2}{*}{$\mathrm{DG} \times \mathrm{AFC}$} & & & & $5.800 * * *$ & & & & \\
\hline & & & & $\{0.0000\}$ & & & & \\
\hline \multirow[t]{2}{*}{$\mathrm{UG} \times \mathrm{AFC}$} & & & & 0.8920 & & & & \\
\hline & & & & $\{0.1315\}$ & & & & \\
\hline \multirow[t]{2}{*}{ Outch $\times$ DG } & & & & & $1.552^{* * *}$ & & & \\
\hline & & & & & $\{0.0000\}$ & & & \\
\hline \multirow[t]{2}{*}{ Ratch $\times$ DG } & & & & & -0.0806 & & & \\
\hline & & & & & $\{0.7383\}$ & & & \\
\hline \multirow[t]{3}{*}{ Outch×UG } & & & & & - & & & \\
\hline & & & & & $1.085^{* * *}$ & & & \\
\hline & & & & & $\{0.0000\}$ & & & \\
\hline \multirow[t]{3}{*}{ Ratch $\times U G$} & & & & & - & & & \\
\hline & & & & & $1.257 * * *$ & & & \\
\hline & & & & & $\{0.0000\}$ & & & \\
\hline \multirow[t]{2}{*}{ Outch $\times$ DG $\times$ AFC } & & & & & & $5.910 * * *$ & & \\
\hline & & & & & & $\{0.0000\}$ & & \\
\hline \multirow[t]{2}{*}{ Ratch $\times$ DG $\times$ AFC } & & & & & & -0.6770 & & \\
\hline & & & & & & $\{0.5468\}$ & & \\
\hline \multirow[t]{2}{*}{ Outch $\times \mathrm{UG} \times \mathrm{AFC}$} & & & & & & $1.760 * *$ & & \\
\hline & & & & & & $\{0.0144\}$ & & \\
\hline \multirow[t]{2}{*}{ Ratch $\times \mathrm{UG} \times \mathrm{AFC}$} & & & & & & 0.8920 & & \\
\hline & & & & & & $\{0.1315\}$ & & \\
\hline INV & & & & & & & $-1.472 * * *$ & \\
\hline & & & & & & & $\{0.0000\}$ & \\
\hline $\mathrm{INV} \times \mathrm{AFC}$ & & & & & & & -1.270 & \\
\hline & & & & & & & $\{0.1408\}$ & \\
\hline Emerg $\times$ AFC $\times$ Event & & & & & & & & -0.4733 \\
\hline & & & & & & & & $\{0.2166\}$ \\
\hline Leg_orig $\times$ AFC $\times$ Event & & & & & & & & $-1.119 * * *$ \\
\hline & & & & & & & & $\{0.0000\}$ \\
\hline Ex_reg $\times$ AFC $\times$ Event & & & & & & & & -0.4733 \\
\hline & & & & & & & & $\{0.2166\}$ \\
\hline Asean $\times$ AFC $\times$ Event & & & & & & & & -0.3816 \\
\hline & & & & & & & & $\{0.3442\}$ \\
\hline Adj. R-sq & 0.0553 & 0.0695 & 0.0560 & 0.0822 & 0.0609 & 0.0814 & 0.0718 & 0.0695 \\
\hline Nobs & 10906 & 10906 & 10906 & 10906 & 10906 & 10906 & 10906 & 10906 \\
\hline
\end{tabular}

This table presents the panel estimation results for stock market realized volatilities over the sample 7/1/1997 to 30/8/2001. Model specifications are based on Eq. (4-8) and coefficients are scaled by 1000 . The crisis periods are from 1/7/1997-30/1/1998 (AFC) and the EMFC includes the sum of the Asian, Russian (1/8/1998-30/10/1998), Brazilian (1/2/1999-28/2/1999) and Turkish (1/2/2001-28/2/2001) financial crises. The AFC/EMFC; UG/DG; outch/ratch and national market attribute coefficients shown are from separate regressions to avoid collinearity issues. ${ }^{*}, * *$ and ${ }^{* * *}$ denote significance at the 10,5 and $1 \%$ levels. 
Table 4. Impact of different types of sovereign ratings on FX market realized volatility in financial crises

\begin{tabular}{|c|c|c|c|c|c|c|c|c|}
\hline FX VOL & (1) & $(2)$ & (3) & (4) & (5) & (6) & (7) & (8) \\
\hline Const & $\begin{array}{l}-5.732^{* * *} \\
\{0.0000\}\end{array}$ & $\begin{array}{l}-5.314^{* * * *} \\
\{0.0000\}\end{array}$ & $\begin{array}{l}-4.845^{* * *} \\
\{0.0000\}\end{array}$ & $\begin{array}{l}-5.713^{* * *} \\
\{0.0000\}\end{array}$ & $\begin{array}{l}-4.934^{* * *} \\
\{0.0000\}\end{array}$ & $\begin{array}{l}-5.723^{* * *} \\
\{0.0000\}\end{array}$ & $\begin{array}{l}-5.688^{* * *} \\
\{0.0000\}\end{array}$ & $\begin{array}{l}-5.229 * * * \\
\{0.0000\}\end{array}$ \\
\hline Event & $\begin{array}{l}-1.530^{*} \\
\{0.0879\}\end{array}$ & $\begin{array}{l}-1.520 * \\
\{0.0898\}\end{array}$ & $\begin{array}{l}-1.376 \\
\{0.1236\}\end{array}$ & $\begin{array}{l}-1.532 * \\
\{0.0877\}\end{array}$ & $\begin{array}{l}-1.469 * \\
\{0.0982\}\end{array}$ & $\begin{array}{l}-1.426^{*} \\
\{0.0870\}\end{array}$ & $\begin{array}{l}-1.523^{*} \\
\{0.0883\}\end{array}$ & $\begin{array}{l}-0.9881 \\
\{0.1319\}\end{array}$ \\
\hline Lag Event & $\begin{array}{l}-0.4718 \\
\{0.1187\}\end{array}$ & $\begin{array}{l}-0.4621 \\
\{0.1225\}\end{array}$ & $\begin{array}{l}-0.3183 \\
\{0.2936\}\end{array}$ & $\begin{array}{l}-0.4740 \\
\{0.1173\}\end{array}$ & $\begin{array}{l}-0.4108 \\
\{0.1720\}\end{array}$ & $\begin{array}{l}-0.3678 \\
\{0.1235\}\end{array}$ & $\begin{array}{l}-0.4653 \\
\{0.1192\}\end{array}$ & $\begin{array}{l}-0.4641 \\
\{0.1219\}\end{array}$ \\
\hline CCR & $\begin{array}{l}0.4194 * * * \\
\{0.0000\}\end{array}$ & $\begin{array}{l}0.3870 * * * \\
\{0.0000\}\end{array}$ & $\begin{array}{l}0.3717 * * * \\
\{0.0000\}\end{array}$ & $\begin{array}{l}0.4173^{* * *} \\
\{0.0000\}\end{array}$ & $\begin{array}{l}0.3751 * * * \\
\{0.0000\}\end{array}$ & $\begin{array}{l}0.4182 * * * \\
\{0.0000\}\end{array}$ & $\begin{array}{l}0.4269 * * * \\
\{0.0000\}\end{array}$ & $\begin{array}{l}0.3813^{* * *} \\
\{0.0000\}\end{array}$ \\
\hline AFC & & $\begin{array}{l}0.4803^{* * *} \\
\{0.0018\}\end{array}$ & & $\begin{array}{l}0.4910^{* *} \\
\{0.0144\}\end{array}$ & & $\begin{array}{l}0.4740^{* * *} \\
\{0.0046\}\end{array}$ & $\begin{array}{l}1.234 * * * \\
\{0.0000\}\end{array}$ & $\begin{array}{l}0.4469 * * * \\
\{0.0033\}\end{array}$ \\
\hline EMFC & & $\begin{array}{l}0.1939 * * \\
\{0.0123\}\end{array}$ & & & & & & \\
\hline DG & & & $\begin{array}{l}1.1859 * * * \\
\{0.0000\}\end{array}$ & & & & & \\
\hline UG & & & $\begin{array}{l}- \\
0.5715^{* * *} \\
\{0.0000\}\end{array}$ & & & & & \\
\hline $\mathrm{DG} \times \mathrm{AFC}$ & & & & $\begin{array}{l}7.650 \\
\{0.1096\}\end{array}$ & & & & \\
\hline $\mathrm{UG} \times \mathrm{AFC}$ & & & & $\begin{array}{l}-0.4710 \\
\{0.8512\}\end{array}$ & & & & \\
\hline Outch $\times$ DG & & & & & $\begin{array}{l}0.0369 \\
\{0.8624\}\end{array}$ & & & \\
\hline Ratch $\times$ DG & & & & & $\begin{array}{l}1.836 * * * \\
\{0.0000\}\end{array}$ & & & \\
\hline Outch $\times$ UG & & & & & $\begin{array}{l}-1.148^{* * *} \\
\{0.0000\}\end{array}$ & & & \\
\hline Ratch $\times$ UG & & & & & $\begin{array}{l}0.8182^{* * *} \\
\{0.0000\}\end{array}$ & & & \\
\hline Outch $\times$ DG $\times$ AFC & & & & & & $\begin{array}{l}0.6110 \\
\{0.8488\}\end{array}$ & & \\
\hline Ratch $\times$ DG $\times$ AFC & & & & & & $\begin{array}{l}5.177^{* * *} \\
\{0.0001\}\end{array}$ & & \\
\hline Outch $\times \mathrm{UG} \times \mathrm{AFC}$ & & & & & & $\begin{array}{l}-8.810^{* * *} \\
\{0.0000\}\end{array}$ & & \\
\hline Ratch $\times \mathrm{UG} \times \mathrm{AFC}$ & & & & & & $\begin{array}{l}-0.4720 \\
\{0.8512\}\end{array}$ & & \\
\hline INV & & & & & & & $\begin{array}{l}-2.510 \\
\{0.3858\}\end{array}$ & \\
\hline $\mathrm{INV} \times \mathrm{AFC}$ & & & & & & & $\begin{array}{l}-8.66 * * * \\
\{0.0040\}\end{array}$ & \\
\hline Emerg $\times$ AFC $\times$ Event & & & & & & & & $\begin{array}{l}22.30 * \\
\{0.0873\}\end{array}$ \\
\hline Leg_orig $\times$ AFC $\times$ Event & & & & & & & & $\begin{array}{l}-40.06^{* * *} \\
\{0.0000\}\end{array}$ \\
\hline Ex_reg $\times$ AFC $\times$ Event & & & & & & & & $\begin{array}{l}-23.25^{*} \\
\{0.0837\}\end{array}$ \\
\hline Asean $\times$ AFC $\times$ Event & & & & & & & & $\begin{array}{l}-24.33^{*} \\
\{0.0731\}\end{array}$ \\
\hline Adj. R-sq & 0.0907 & 0.0921 & 0.0934 & 0.0925 & 0.1019 & 0.0920 & 0.0926 & 0.1026 \\
\hline Nobs & 10906 & 10906 & 10906 & 10906 & 10906 & 10906 & 10906 & 10906 \\
\hline
\end{tabular}

This table presents the panel data results for FX market realized volatilities over the sample 7/1/1997 to 30/8/2001. Model specifications are based on Eq. (4-8) and coefficients are scaled by 1000 . The crisis periods are from 1/7/1997-30/1/1998 (AFC); and the EMFC includes the sum of the Asian, Russian (1/8/1998-30/10/1998), Brazilian (1/2/1999-28/2/1999) and Turkish (1/2/2001-28/2/2001) financial crises. The AFC/EMFC; UG/DG; outch/ratch and national market attribute coefficients shown are from separate regressions to avoid collinearity issues. *, ** and ${ }^{* * *}$ denote significance at the 10,5 and $1 \%$ levels. 
Table 5. Incremental Impact of sovereign ratings on realized correlation between stock and currency markets

\begin{tabular}{|c|c|c|c|c|c|c|}
\hline & $(1)$ & (2) & (3) & (4) & (5) & (6) \\
\hline Const & $\begin{array}{l}-0.0211 \\
\{0.4876\}\end{array}$ & $\begin{array}{l}-0.041619 \\
\{0.2517\}\end{array}$ & $\begin{array}{l}-0.0065 \\
\{0.8256\}\end{array}$ & $\begin{array}{l}-0.0069 \\
\{0.8145\}\end{array}$ & $\begin{array}{l}-0.0065 \\
\{0.8256\}\end{array}$ & $\begin{array}{l}-0.0064 \\
\{0.8272\}\end{array}$ \\
\hline Event & $\begin{array}{l}0.0164 \\
\{0.6870\}\end{array}$ & $\begin{array}{l}-0.017335 \\
\{0.6287\}\end{array}$ & $\begin{array}{l}-0.0083 \\
\{0.8190\}\end{array}$ & $\begin{array}{l}-0.0116 \\
\{0.7483\}\end{array}$ & $\begin{array}{l}-0.0083 \\
\{0.8190\}\end{array}$ & $\begin{array}{l}-0.0069 \\
\{0.8482\}\end{array}$ \\
\hline Lag Event & $\begin{array}{l}0.0295 \\
\{0.2112\}\end{array}$ & $\begin{array}{l}0.028495 \\
\{0.2035\}\end{array}$ & $\begin{array}{l}0.0281 \\
\{0.2277\}\end{array}$ & $\begin{array}{l}0.0281 \\
\{0.2278\}\end{array}$ & $\begin{array}{l}0.0281 \\
\{0.2277\}\end{array}$ & $\begin{array}{l}0.0281 \\
\{0.2271\}\end{array}$ \\
\hline CCR & $\begin{array}{l}-0.0002 \\
\{0.9311\}\end{array}$ & $\begin{array}{l}0.004205 \\
\{0.1550\}\end{array}$ & $\begin{array}{l}-0.0004 \\
\{0.8388\}\end{array}$ & $\begin{array}{l}-0.0004 \\
\{0.8509\}\end{array}$ & $\begin{array}{l}-0.0004 \\
\{0.8388\}\end{array}$ & $\begin{array}{l}-0.0004 \\
\{0.8367\}\end{array}$ \\
\hline AFC & $\begin{array}{l}0.0056 \\
\{0.5942\}\end{array}$ & & & & & \\
\hline EMFC & $\begin{array}{l}0.0048 \\
\{0.4989\}\end{array}$ & & & & & \\
\hline High_vol & & $\begin{array}{l}0.0211^{* * *} \\
\{0.0017\}\end{array}$ & $\begin{array}{l}0.0205^{* * *} \\
\{0.0022\}\end{array}$ & $\begin{array}{l}0.0205^{* * *} \\
\{0.0022\}\end{array}$ & $\begin{array}{l}0.0205^{* * *} \\
\{0.0022\}\end{array}$ & $\begin{array}{l}0.0205^{* * *} \\
\{0.0023\}\end{array}$ \\
\hline Outch $\times$ DG $\times$ Event & $\begin{array}{l}0.1042^{*} \\
\{0.0906\}\end{array}$ & & & & & \\
\hline Ratch $\times$ DG $\times$ Event & $\begin{array}{l}0.0881 \\
\{0.2659\}\end{array}$ & & & & & \\
\hline Outch $\times$ UG $\times$ Event & $\begin{array}{l}-0.2750 * \\
\{0.0659\}\end{array}$ & & & & & \\
\hline Ratch $\times U G \times$ Event & $\begin{array}{l}-0.1242 \\
\{0.1373\}\end{array}$ & & & & & \\
\hline INV & & $\begin{array}{l}-0.0469 * * * \\
\{0.0057\}\end{array}$ & & & & \\
\hline $\mathrm{INV} \times \mathrm{AFC}$ & & $\begin{array}{l}0.0152 \\
\{0.1751\}\end{array}$ & & & & \\
\hline Emerg $\times$ AFC $\times$ Event & & & $\begin{array}{c}-0.4128^{*} \\
\{0.0516\}\end{array}$ & & & \\
\hline Leg_orig $\times$ AFC $\times$ Event & & & & $\begin{array}{l}-0.4591 * * * \\
\{0.0037\}\end{array}$ & & \\
\hline Ex_reg $\times$ AFC $\times$ Event & & & & & $\begin{array}{l}-0.4380^{*} \\
\{0.0561\}\end{array}$ & \\
\hline Asean $\times$ AFC $\times$ Event & & & & & & $\begin{array}{l}-0.4875^{* *} \\
\{0.0117\}\end{array}$ \\
\hline Adj. R-sq & 0.0050 & 0.0063 & 0.0058 & 0.0057 & 0.0058 & 0.0059 \\
\hline Nobs & 10906 & 10906 & 10906 & 10906 & 10906 & 10906 \\
\hline
\end{tabular}

This table presents the panel estimation results for cross-stock-FX market realized correlations over the sample 7/1/1997 to 30/8/2001. Model specifications are based on Eq. (4-8). The crisis periods are from 1/7/1997-30/1/1998 (AFC) and the EMFC includes the sum of the Asian, Russian (1/8/199830/10/1998), Brazilian (1/2/1999-28/2/1999) and Turkish (1/2/2001-28/2/2001) financial crises. *, ** and $* * *$ denote significance at the 10,5 and $1 \%$ levels. 
Table 6. Rating spill over effects in the Asia-Pacific

\begin{tabular}{|c|c|c|c|c|c|c|c|c|c|}
\hline Spill over from: & Indonesia & & & Philippines & & & Thailand & & \\
\hline Dep. Variable & RV-stocks & RV-FX & RC-stocks-FX & RV-stocks & RV-FX & RC-stocks-FX & RV-stocks & RV-FX & RC-stocks-FX \\
\hline Constant & $\begin{array}{l}4.2228^{* * *} \\
\{0.0001\}\end{array}$ & $\begin{array}{l}-1.318^{* * *} \\
\{0.0000\}\end{array}$ & $\begin{array}{l}-0.0848 \\
\{0.1066\}\end{array}$ & $\begin{array}{l}0.3833 * * \\
\{0.0336\}\end{array}$ & $\begin{array}{l}-8.120 * * * \\
\{0.0000\}\end{array}$ & $\begin{array}{l}0.2908 * * * \\
\{0.0056\}\end{array}$ & $\begin{array}{l}6.014^{* * *} \\
\{0.0000\}\end{array}$ & $\begin{array}{l}-3.628 * * * \\
\{0.0000\}\end{array}$ & $\begin{array}{l}-0.0518 \\
\{0.1941\}\end{array}$ \\
\hline Event_spill & $\begin{array}{l}0.0888 \\
\{0.7219\}\end{array}$ & $\begin{array}{l}-0.0149 \\
\{0.2525\}\end{array}$ & $\begin{array}{l}-0.0060 \\
\{0.6322\}\end{array}$ & $\begin{array}{l}-0.0905^{* * *} \\
\{0.0000\}\end{array}$ & $\begin{array}{l}-0.5894^{* * *} \\
\{0.0000\}\end{array}$ & $\begin{array}{l}-0.0600 * * * \\
\{0.0004\}\end{array}$ & $\begin{array}{l}-0.2116 \\
\{0.1986\}\end{array}$ & $\begin{array}{l}-0.0767 \\
\{0.3435\}\end{array}$ & $\begin{array}{l}0.0929 * * * \\
\{0.0000\}\end{array}$ \\
\hline CCR_spill & $\begin{array}{l}-0.0305 \\
\{0.1515\}\end{array}$ & $\begin{array}{l}0.0154^{* * *} \\
\{0.0000\}\end{array}$ & $\begin{array}{l}-0.0009 \\
\{0.4893\}\end{array}$ & $\begin{array}{l}-0.0102 \\
\{0.5133\}\end{array}$ & $\begin{array}{l}0.2524^{* * *} \\
\{0.0013\}\end{array}$ & $\begin{array}{l}-0.0298 * * * \\
\{0.0018\}\end{array}$ & $\begin{array}{l}-0.4278 * * * \\
\{0.0000\}\end{array}$ & $\begin{array}{l}-0.2381 * * * \\
\{0.0000\}\end{array}$ & $\begin{array}{l}0.0024 \\
\{0.4221\}\end{array}$ \\
\hline CCR_own & $\begin{array}{l}-0.0898 \\
\{0.1793\}\end{array}$ & $\begin{array}{l}0.0839 * * * \\
\{0.0000\}\end{array}$ & $\begin{array}{l}0.0039 \\
\{0.2491\}\end{array}$ & $\begin{array}{l}-0.0007 \\
\{0.8939\}\end{array}$ & $\begin{array}{l}0.3943 * * * \\
\{0.0000\}\end{array}$ & $\begin{array}{l}-0.0013 \\
\{0.5402\}\end{array}$ & $\begin{array}{l}0.1001^{*} \\
\{0.0663\}\end{array}$ & $\begin{array}{l}0.4466^{* * *} \\
\{0.0000\}\end{array}$ & $\begin{array}{l}-0.0003 \\
\{0.9014\}\end{array}$ \\
\hline AFC & $\begin{array}{l}2.372^{* * *} \\
\{0.0000\}\end{array}$ & $\begin{array}{l}0.3115^{* * *} \\
\{0.0000\}\end{array}$ & $\begin{array}{l}0.0123 \\
\{0.3703\}\end{array}$ & $\begin{array}{l}0.2149 * * * \\
\{0.0000\}\end{array}$ & $\begin{array}{l}0.2595 \\
\{0.1673\}\end{array}$ & $\begin{array}{l}0.0265^{* *} \\
\{0.0265\}\end{array}$ & $\begin{array}{l}3.400 * * * \\
\{0.0000\}\end{array}$ & $\begin{array}{l}1.075 * * * \\
\{0.0000\}\end{array}$ & $\begin{array}{l}-0.0006 \\
\{0.9662\}\end{array}$ \\
\hline AFC $\times$ Event & $\begin{array}{l}3.029 * * * \\
\{0.0000\}\end{array}$ & $\begin{array}{l}0.3319 * * * \\
\{0.0000\}\end{array}$ & $\begin{array}{l}-0.1025^{* * *} \\
\{0.0000\}\end{array}$ & $\begin{array}{l}-0.9587^{* * *} \\
\{0.0000\}\end{array}$ & $\begin{array}{l}1.035 \\
\{0.1095\}\end{array}$ & $\begin{array}{l}-0.1273^{* * *} \\
\{0.0059\}\end{array}$ & $\begin{array}{l}-0.7867 \\
\{0.8145\}\end{array}$ & $\begin{array}{l}0.8087 * * * \\
\{0.0005\}\end{array}$ & $\begin{array}{l}-0.1078 \\
\{0.5730\}\end{array}$ \\
\hline Emerg $\times$ AFC $\times$ Ev_spill & $\begin{array}{l}0.7576^{* * *} \\
\{0.0000\}\end{array}$ & $\begin{array}{l}-0.8859 * * * \\
\{0.0000\}\end{array}$ & $\begin{array}{l}0.1545^{* * *} \\
\{0.0000\}\end{array}$ & $\begin{array}{l}1.012^{* * *} \\
\{0.0000\}\end{array}$ & $\begin{array}{l}-27.42^{* * *} \\
\{0.0000\}\end{array}$ & $\begin{array}{l}0.3440 \text { *** } \\
\{0.0000\}\end{array}$ & $\begin{array}{l}0.3828 \\
\{0.9330\}\end{array}$ & $\begin{array}{l}2.421 * * * \\
\{0.0000\}\end{array}$ & $\begin{array}{l}0.0004 \\
\{0.9988\}\end{array}$ \\
\hline Leg_orig $\times$ AFC $\times$ Ev_spill & $\begin{array}{l}0.2626 * * * \\
\{0.0074\}\end{array}$ & $\begin{array}{l}0.2705^{* * *} \\
\{0.0000\}\end{array}$ & $\begin{array}{l}-0.0330 * * * \\
\{0.0000\}\end{array}$ & $\begin{array}{l}0.9668^{* * *} \\
\{0.0000\}\end{array}$ & $\begin{array}{l}-19.54 * * * \\
\{0.0000\}\end{array}$ & $\begin{array}{l}1.766 * * * \\
\{0.0000\}\end{array}$ & $\begin{array}{l}2.705 \\
\{0.6365\}\end{array}$ & $\begin{array}{l}1.919 * * * \\
\{0.0000\}\end{array}$ & $\begin{array}{l}0.0258 \\
\{0.6467\}\end{array}$ \\
\hline Ex_reg $\times$ AFC $\times$ Ev_spill & $\begin{array}{l}-1.103^{* * *} \\
\{0.0000\}\end{array}$ & $\begin{array}{l}-0.6672^{* * *} \\
\{0.0000\}\end{array}$ & $\begin{array}{l}0.0934^{* * * *} \\
\{0.0000\}\end{array}$ & $\begin{array}{l}3.157^{* * *} \\
\{0.0000\}\end{array}$ & $\begin{array}{l}-18.00^{* * *} \\
\{0.0000\}\end{array}$ & $\begin{array}{l}0.1951^{* * *} \\
\{0.0000\}\end{array}$ & $\begin{array}{l}5.782 \\
\{0.4792\}\end{array}$ & $\begin{array}{l}1.420 * * * \\
\{0.0000\}\end{array}$ & $\begin{array}{l}-0.0473 \\
\{0.8093\}\end{array}$ \\
\hline Asean $\times$ AFC $\times$ Ev_spill & $\begin{array}{l}-1.458 * * * \\
\{0.0000\}\end{array}$ & $\begin{array}{l}-1.435 * * * \\
\{0.0000\}\end{array}$ & $\begin{array}{l}0.2401 * * * \\
\{0.0000\}\end{array}$ & $\begin{array}{l}-1.373^{* * *} \\
\{0.0000\}\end{array}$ & $\begin{array}{l}-38.17 * * * \\
\{0.0000\}\end{array}$ & $\begin{array}{l}-0.6732 * * * \\
\{0.0000\}\end{array}$ & $\begin{array}{l}2.992 \\
\{0.4531\}\end{array}$ & $\begin{array}{l}1.748^{* * *} \\
\{0.0000\}\end{array}$ & $\begin{array}{l}0.3388^{* * *} \\
\{0.0013\}\end{array}$ \\
\hline $\begin{array}{l}\text { Adj. R-sq } \\
\text { Nobs }\end{array}$ & $\begin{array}{l}0.0831 \\
9696\end{array}$ & $\begin{array}{l}0.0888 \\
9696\end{array}$ & $\begin{array}{l}0.0047 \\
9696\end{array}$ & $\begin{array}{l}0.0804 \\
9704\end{array}$ & $\begin{array}{l}0.0918 \\
9704\end{array}$ & $\begin{array}{l}0.0066 \\
9704\end{array}$ & $\begin{array}{l}0.0804 \\
9704\end{array}$ & $\begin{array}{l}0.0938 \\
9704\end{array}$ & $\begin{array}{l}0.0042 \\
9704\end{array}$ \\
\hline
\end{tabular}

This table presents the rating spill over effects from Indonesia, Philippines and Thailand to other sample countries' stock and FX market volatilities and cross-stock-FX market correlations in the Asia-pacific region. The model specifications are based on Eq. (9). The AFC crisis period is from 1/7/1997-30/1/1998. *, ** and *** denote significance at the 10, 5 and $1 \%$ levels. 


\section{Appendix}

Table A.1. GMT Offsets and Stock Exchange Trading Times (Local and GMT) for all countries examined.

\begin{tabular}{lccc}
\hline \multicolumn{1}{c}{ Country } & GMT Offset & Local Trading Hours & GMT Trading Hours \\
\hline Australia & +10 & $10: 00-16: 00$ & $0: 00-6: 00$ \\
& +11 (DST) & & $23: 00-5: 00$ \\
Hong Kong & +8 & $10: 00-16: 00$ & $2: 00-8: 00$ \\
Japan & +9 & $9.00-15.00$ & $0: 00-6: 00$ \\
Indonesia & +7 & Monday to Thursday: & Monday to Thursday: \\
& & Morning Session: & Morning Session: \\
& & $09: 30-12: 00$ & $02: 30-5: 00$ \\
& & Afternoon Session: & Afternoon Session: \\
& & $13: 30-16: 00$ & $6: 30-9: 00$ \\
& & Friday: & Friday: \\
& & Morning Session: & Morning Session: \\
& & $09: 30-12: 00$ & $02: 30-5: 00$ \\
Philippines & +8 & Afternoon Session: & Afternoon Session: \\
Singapore & +8 & $14: 00-16: 00$ & $7: 00-9: 00$ \\
South Korea & +9 & $9: 30-12: 00$ & $1: 30-4: 00$ \\
Taiwan & +8 & $9: 00-17: 00$ & $1: 00-9: 00$ \\
Thailand & +7 & $9: 00-15: 15$ & $0: 00-6: 15$ \\
& & $9: 00-13: 30$ & $1: 00-5: 30$ \\
& & Morning Session: & Morning Session: \\
& & $10: 00-12: 30$ & $3: 00-5: 30$ \\
& & Afternoon Session: & Afternoon Session: \\
& & $14: 30-16: 30$ & $7: 30-9: 30$ \\
& & &
\end{tabular}


Table A.2. Chronology of Sovereign Rating and Outlook revisions from 6 Jan 1997 to 30 Aug 2001

\begin{tabular}{|c|c|c|c|}
\hline Year & Date & Rating revisions & Outlook/watch revisions \\
\hline \multirow[t]{12}{*}{1997} & 21-Feb-97 & Philippines rating upgraded $\mathrm{BB}$ to $\mathrm{BB}+$ & \\
\hline & 14-May-97 & HK upgraded $\mathrm{A}$ to $\mathrm{A}+$ & HK outlook reduced from positive to stable \\
\hline & 1-Aug-97 & & Thailand was put on watch negative (from stable) \\
\hline & 6-Aug-97 & & Korean outlook revised down to negative \\
\hline & 3-Sep-97 & Thailand rating cut from A to A- & Thai outlook raised to negative from watch negative \\
\hline & 25-Sep-97 & & Philippines outlook revised down to negative \\
\hline & 10-Oct-97 & Indonesia's rating cut by 1 notch BBB to BBB- & \\
\hline & 24-Oct-97 & Korea rating cut 1 notch $\mathrm{AA}$ - to $\mathrm{A}+$; Thailand cut from $\mathrm{A}$ - to $\mathrm{BBB}$ & \\
\hline & 25-Nov-97 & Korea rating cut by 2 notches from $\mathrm{A}+$ to $\mathrm{A}-$ & Korean outlook revised down to watch negative \\
\hline & 11-Dec-97 & Korea rating cut $\mathrm{A}$ - to BBB- & \\
\hline & 22-Dec-97 & Korea rating cut from $\mathrm{BBB}-$ to $\mathrm{B}^{+}$ & \\
\hline & 31-Dec-97 & Indonesia's rating cut by 1 notch BBB- to BB+ & Indonesia's outlook revised down from stable to negative \\
\hline \multirow[t]{11}{*}{1998} & 08-Jan-98 & Thailand rating cut from BBB to BBB- & \\
\hline & 9-Jan-98 & Indonesia's rating cut by 1 notch $\mathrm{BB}+$ to $\mathrm{BB}$ & Indonesia put on watch negative from negative outlook \\
\hline & 16-Jan-98 & & Korea put on watch developing \\
\hline & 27-Jan-98 & Indonesia's rating cut from $\mathrm{BB}$ to $\mathrm{B}$ & \\
\hline & 18-Feb-98 & Korea rating raised by $\mathrm{B}+$ to $\mathrm{BB}+$ & Korea outlook revised up to stable \\
\hline & 23-Feb-98 & & Philippines outlook down to negative \\
\hline & 11-Mar-98 & Indonesian rating cut by 1 notch from $B$ to $B-$ & \\
\hline & 15-May-98 & Indonesian rating cut $\mathrm{B}$ - to $\mathrm{CCC}+$ & \\
\hline & 22-Jun-98 & & HK's outlook reduce from stable to watch negative \\
\hline & 8-Jul-98 & & Indonesia's outlook revised up from watch negative to negative \\
\hline & 31-Aug-98 & HK rating downgraded $\mathrm{A}+$ to $\mathrm{A}$ & HK's outlook improved to negative from watch negative \\
\hline \multirow[t]{10}{*}{1999} & 4-Jan-99 & & Korea outlook revised up to positive \\
\hline & 6-Jan-99 & & Philipines outlook revised up to stable \\
\hline & 25-Jan-99 & Korea rating upgraded 1 notch $\mathrm{BB}+$ to $\mathrm{BBB}-$ & \\
\hline & 30-Mar-99 & Indonesia rating cut from $\mathrm{CCC}+$ to $\mathrm{SD}$ & \\
\hline & 31-Mar-99 & Indonesia rating raised from $\mathrm{SD}$ back to $\mathrm{CCC}+$ & Indonesia's outlook moved up to stable \\
\hline & 5-May-99 & & Thailand outlook revised up from negative to stable \\
\hline & 17-May-99 & Australia rating raised from $\mathrm{AA}$ to $\mathrm{AA}+$ & Australia's outlook revised down from positive to stable \\
\hline & 13-Sep-99 & & Indonesian's outlook revised down from stable to watch negative \\
\hline & 11-Nov-99 & Korea rating upgraded 1 notch BBB- to BBB & \\
\hline & 7-Dec-99 & & HK outlook improved from negative to stable \\
\hline \multirow[t]{4}{*}{2000} & 7-Apr-00 & Indonesian rating cut $\mathrm{CCC}+$ to $\mathrm{SD}$ & \\
\hline & 2-Oct-00 & Indonesia rating upgraded from $\mathrm{SD}$ to $\mathrm{B}-$ & Indonesia's outlook stable \\
\hline & 19-Oct-00 & & Philippines outlook down to negative \\
\hline & 6-Dec-00 & & Taiwan outlook revised down from stable to negative \\
\hline \multirow[t]{6}{*}{2001} & 8-Feb-01 & HK rating upgraded 1 notch from $\mathrm{A}$ to $\mathrm{A}+$ & \\
\hline & 22-Feb-01 & Japan's rating cut by 1 notch from AAA to AA+ & \\
\hline & 8-Mar-01 & & Indonesia outlook revised down to negative \\
\hline & 21-May-01 & Indonesia's rating cut by 1 notch from B- to CCC+ & \\
\hline & 26-Jul-01 & Taiwan rating cut by 1 notch $\mathrm{AA}+$ to $\mathrm{AA}$ & \\
\hline & 30-Jul-01 & & Indonesia outlook revised up from negative to stable \\
\hline
\end{tabular}

